\title{
LUCA, as our father
}

Matteo Cavalli-Sforza 1, Francesco Cavalli-Sforza 2,*, Luca Tommaso Cavalli-Sforza 3,‡ Violetta Cavalli-Sforza 4

Received: 31 Mar 2021

Accepted: 17 Sep 2021

Published: 16 Oct 2021

Copyright: (c) 2021 by the author(s). This is an Open Access article distributed under the terms of the Creative Commons License Attribution 4.0 International (CC BY 4.0), which permits unrestricted use, distribution, and reproduction in any medium or format, provided the original work is correctly credited.

Publisher's Note: Pivot Science Publication Corp. remains neutral with regard to jurisdictional claims in published maps and institutional affiliations.
1. Institut de Física d'Altes Energies (IFAE) at the Universitat Autònoma de Barcelona, Lives in Barcelona, Spain; E-Mail: matteo@ifae.es

2. Independent Communication Professional, Lives in Marradi (Florence), Italy

3. Lives in Belluno, Italy; E-Mail: tommaso.cavalli.sforza@gmail.com

4. Al Akhawayn University in Ifrane, Lives in Zaouiyat Ben Smim, Morocco; E-Mail: V.CavalliSforza@aui.ma

¥ Former affiliation: WHO Regional Adviser in Nutrition, Manila, Philippines

* Correspondence: Francesco Cavalli-Sforza;

E-Mail: francescocavallisforza@gmail.com

When Luca was in Cambridge in 1948-1950, working as a research assistant for Ronald A. Fisher, he would at times walk with his professor through the large garden of the Department of Genetics, where experiments were carried out on different kinds of plants, such as Mendel's peas and certain polyploids. The two would talk at length. Luca had a lot of questions to ask Fisher, but one day he was asked one himself: "Why do people do science?"

Luca thought a while about it - he later confessed that he had never considered this before - then he answered: "Out of curiosity?"

"No," - said Fisher - "They do it out of ambition."

Luca, all his life, had done science because of his boundless curiosity, although he appreciated recognition for his work when it came. He bequeathed this attitude to his children. There are four of us, all born between 1946 and 1956, and we all are engaged in very different activities in life-high-energy physics, communication, medicine and nutrition, computer science-but all of us on the path of research (not of business). So, we thought of contributing to this new scientific journal (HPGG) - that Luca would have loved-by looking into what each of us learned from the man who was a scientist, whom everyone knew as a steadfast researcher and polymath, but who for us was first of all our father. 


\section{Curiosity, Research, and Inspiration}

Matteo: The news of Luca's passing was everywhere within hours of his demise. I received the first personal message that very evening. Although I was aware of how well-known he was, I had not realized that he was such a public figure. I should not have been surprised. I should have imagined that the influence he had on me, growing up as the firstborn son among four siblings, was just an instance of the influence he had on generations of scientists, friends, and colleagues.

In my case, the strongest influence was scientific. I am a retired experimental particle physicist, still active in the field because my research interest has been and still is the strongest driving force in my life. Of course, I cannot tell how it would have been, were it not for Luca! How strong was the desire for recognition (the "ambition" Fisher referred to) in Luca? He was very competitive, so I think that this motivation was there, strongly, but I think that it took second place to curiosity. To the very end of his life, his curiosity knew no limits. This was probably what drove him to create new fields-meanwhile launching the careers of several disciples. His scientific interests and knowledge were exceptionally broad, as a matter of course. After he died, I found out that in his last years he used to tear out articles from the journals he subscribed to and set them aside, classifying them by subjects such as neuropsychology, brain research, sociology, the domestication of animals, and more.

Francesco: I was born in Cambridge, at the time when Luca had moved the family there to work with Fisher. As the second-born son, I probably did not feel the impact of expectations usually falling on the first-born. I have always worked in communication, both in words and images, looking rather into the future than into the past, trying to give shape to things that would not be there unless they were deliberately created, in film, video, TV programs, and books. The family imprint was there all the time, not just Luca's: in the generation before him, we also had scientists, writers, and pioneers within the family. I graduated in philosophy with an emphasis on language and I worked a lot on the transmission of knowledge through the media. The interest in spreading knowledge brought me closer to my father, who shared it. In the mid-1970s, we prepared together the script for a series of videocassettes to teach genetics, but the times were not ripe for anything like it yet, at least not in Italy.

One evening, in 1991, Luca called me from Stanford. I was in Milan at the time, directing a fantasy series for children on national television. He said: "An Italian publisher wants to send a reporter here to write a book on my research. I thought it would be annoying to have someone around for a couple of months asking questions daily. Why don't you come over and we write it together?" I loved the idea and moved to 
Stanford as soon as my contract in Milan was over. The book we wrote was centered on Luca's multidisciplinary approach to human evolution. The title of the English edition was The Great Human Diasporas-A History of Diversity and Evolution, and it was followed by three more popular science books and by some seven series of science courses for Italian kids in junior and senior high school.

We worked almost shoulder to shoulder for the following twenty years, not just on books but on articles for dailies and encyclopedias, and talks at conferences and symposia. First, we would talk at length-and I would study-then each of us would write a chapter and pass it on to the other, who would work on it and pass it back. In the beginning, each piece would go to and fro up to eight times, before we were both satisfied. By the end, it was enough to exchange a few words on what to say, then usually I would write the piece and Luca would check it. It was a fantastic cooperative arrangement for me, as it has been for many of his colleagues. I have a few great colleagues and friends myself, but I do not expect to find such a deep and smooth collaboration with anyone again.

Tommaso: In writing about our father's influence on our lives, we cannot forget to talk about our mother Alba and her role as well, because together their contributions to our education were highly complementary. The most important stimuli received from my parents were, for me, the desire:

- to explore and understand the world we live in;

- to understand who we are and how we function, to stay in good health; and

- to know our individual interests and skills.

Since most of our life is spent working, understanding our interests and skills will help us find those directions in life that provide the most satisfaction and sense of achievement.

Our father always had an overwhelming interest in his work and, if he was not working, he risked feeling bored or depressed. In the first years of our life, he left our mother mostly in charge of raising us children and of cultivating our interest in sports, culture, literature, music, and art. But he always looked after our health.

Luca always had an interest in stimulating our curiosity in the scientific field, but most of all in helping us find our own path to personal development and interests. He inspired me to study medicine, which proved to be a way to achieve all of the above goals. We were given the freedom to move around and make choices independently from an early age. In elementary school, we went to school by ourselves on foot; in middle school we rode our bicycles all around Milan, discovering its more interesting corners. From the age of 16, the opportunity of having a motorcycle allowed me to make long trips outside town. 
The passion for adventure and exploration was instilled in us before adolescence, with hikes in the Dolomite Mountains to stay in huts and, for some of us, the first mountain climbs. I was 12 when the three of us brothers traveled north to south the length of Italy with our parents, from Milan to Naples, Paestum, and Cape Palinurus, visiting museums and staying overnight at campsites. Violetta, the youngest, stayed home with our grandmothers. Later, a trip to Greece in the family car took us across Yugoslavia and Montenegro, down to the Peloponnese, then the Cyclades, generating a desire to explore the many islands of the Aegean Sea, which all of us-especially Francesco and I-fully satisfied later, in our adult lives.

Violetta: As Luca's youngest and only female offspring, I had a rather unique relationship with him. I was a latecomer somehow among the Cavalli-Sforza children, as I was born about five and a half years after my brother Tommaso, the youngest of the boys. My mother told me that I was most likely conceived in Sicily, during a trip there, which might explain my attraction for the southern Mediterranean regions and my choice of living in Morocco today. When Luca found out that she was pregnant again, he became angry because, so he told her, she could only conceive boys! A rather odd statement for a geneticist to make, but one that I treasure because it shows the human face of Luca, which accompanied me throughout my life, alongside the professional one.

Due to the age difference with my brothers, I followed my parents to Stanford when they moved there for good in 1971 after a 'trial' stay, when they took most of us to Stanford in 1968 for a year. I was still in high school, and I later spent several years near them as I pursued university studies. While I was not happy to be torn out of my Italian social context at that age, it was undoubtedly a blessing. On one side, it opened up a whole range of options that I would not have had if I had stayed in Italy; on the other, it allowed me to develop a real and strong father-daughter relationship with Luca.

In the years before leaving Italy for California, when he was commuting daily between Milan and Pavia for his work, I saw rather little of Luca: briefly at dinner when he ate at home and there were no guests; the few times he took me to the Genetics Institute to show me Drosophilae and explain Mendelian genetics; the few days he spent vacationing with us at the seaside or in the country; and when we played games. At Stanford, by contrast, I had a father who was there most of the time and we were a normal family. We had pets, cats primarily, one of which loved to take a nap on Luca's chest after dinner. I even had a horse for a few years, before entering college. No dogs were allowed, though, after the neighbors' Saint Bernard ravaged our garden, my mother's pride and joy. I made up for that lack now that I live on a farm, by keeping several dogs and other animals. 
I pursued my studies at Stanford because I never received an answer from the only other university I had applied to-UC Davis. Initially, I thought I might follow my father's path, taking a pre-medical and psychology curriculum, thinking I might become a psychiatrist, but I quickly changed my mind. I did not have a good relationship with chemistry, and the reigning paradigm in psychology in those days was behaviorism, which I did not find interesting in the least. I, therefore, decided to take full advantage of the freedom my parents believed we should have in the choice of our professional path and of the US college system, which allows you-even requires you-to study several different subjects before choosing your major. I drew away from the life sciences, tried many different subjects across the social sciences and humanities, and eventually ended up with a degree in civil engineering. Later on, after some work experience and further studies, I veered towards computer science and artificial intelligence for my doctorate.

Matteo: Luca would not have liked the current trend towards preferential funding of applied versus 'curiosity-driven' research. His studies were obviously of the latter type. Going over how the directions of my research evolved over fifty years, I am struck by my incapacity for generating ideas with a profitable side. I wonder how I would have evolved scientifically if he had given me a different example.

Francesco: I agree with that idea. Our father was interested in 'pure' research, in understanding things. He was wary and often critical of 'applied' commercial research and shunned the business proposals he received. He always opposed the patenting of DNA, mainly on the grounds that it would hamper and slow down independent research.

\section{Genetics}

Matteo: Luca had a non-intrusive way of gently pushing me towards what he thought might interest me. One day, he brought home a few glass tubes with Drosophilae in them. This was while I was in high school, studying mainly Italian, Latin, and Greek. Drosophilae are certainly at the origin of my love for hands-on experimental work, which he encouraged me to pursue, telling me that I had some aptitude for it. My early interest in laboratory work did not last more than a couple of years, however, but under Luca's guidance, it evolved into an interest in molecular genetics. At that point, around 1963, still the early days of DNA, RNA, and the genetic code, Luca advised me to study physics, rather than biology, because of the better formative potential of physics studies (somewhat similar to the way calculus was placed by Newton at the foundation of physics), despite the enormous potential of the 'new' biology, of which genetics was obviously to be the foundation.

I took his advice, and I never left physics! However, the early exposure to his research left me with a strong interest in the life sciences. 
Francesco: I must have been eight or nine years old when Luca set up a small lab to show us how to experiment with Drosophilae. He brought culture tubes, Petri dishes, agar-agar, a microscope, forceps, cotton wool, and chloroform. I remember breeding Drosophilae, crossing them, examining the hybrids under the microscope, and keeping accurate track of everything in my lab book. It was something so different from what we did at school. I kept at it for several months, until my attention waned.

I rediscovered the intricacies of heredity much later, but I still remember a funny anecdote from those early days. Our father would often speak to us of heredity, even when we were little kids. Matteo, our older brother, would show lively attention to the subject. At some point, the misunderstanding behind it all surfaced: Matteo was convinced that by 'heredity' our parents meant 'inheritance'! We all had a big laugh over that.

\section{Medicine}

Tommaso: At the end of high school, I did not have a clear idea about what direction to take, and it was at that time that my father had his first important influence on my life choices. He told me: "By studying medicine, you will be able to access the fields of science as much as the humanities, depending on where your inclinations will take you."

Having reached the fourth year of medical school, and starting in actual practice, I realized that I did not have much interest in clinical or hospital work. I felt that I could achieve much more by practicing prevention, rather than cure, and the regions of the world where prevention is most needed are those where poverty prevails and health resources are scarce. I felt strongly that working on the prevention of diseases in developing countries could be a stimulating and satisfying activity that would also allow me to explore the world through my job. Early inspiration in this direction probably came from the first studies that Luca did, from the mid-1960s, on the genetics of Pygmies in the Central African Republic, Congo (then Zaire), and elsewhere in the African tropical forests. To get there, he chose to cross the desert with two Land Rovers and, on a subsequent trip, with a trailer in tow. He was fascinated by the desert, its immense spaces, its deep silence, and the infinity of starry nights. When he returned from these trips, his evening slide shows and the stories he told of his adventures must have inspired in us children, studying in Milan in those years, a fervent desire to explore the far corners of the world.

Matteo: Luca's studies had prepared him for a career in medicine, and indeed his first jobs were in hospitals and later in a company making serums and vaccines. He said (and wrote about it, too), that he had left the medical profession back in the 1940s, frustrated by how ineffective 
it was in fighting most disorders. He was certainly affected by the poor health and early death of his father because of high blood pressure that could not then be kept under control with medication. This also left its mark on family life in several ways. It was an interesting experience to have one's family doctor living at home. I do not have many recollections of Luca as my doctor-he usually preferred to rely on other colleagues-but I recall his disappointment with medicines when, as a very small child in the late '40s and early '50s, I was often ill with respiratory ailments. Many of the highly effective antibiotics of today were not available at that time.

Somewhat later, I learned from my father not to unconditionally trust medicines. Sometimes when I asked him whether some medical product was useful, he would answer "Certainly, for the manufacturer!". That was a great lesson in the value of healthy skepticism, an attitude I still have regarding pharmaceutical products. He would sometimes say: "It is not the medicines that cure you, it is your body that wins the wars."

Tommaso: When I completed my medical studies, I knew that I wanted to work in preventive medicine and developing countries. To start working in Italy, however, I identified three possible areas: school medicine, public health, and preventive medicine for workers. I initially chose the first one, which required both clinical work and health education, and left me time to consider my alternatives; but this work was repetitive and not stimulating. Once again, Luca suggested another important avenue for preventive medicine in developing countries: nutrition, which he saw as of the utmost importance to stay in good health, but which was little studied and applied as a branch of medicine fifty years ago. Besides the advantage of being a multidisciplinary field, interacting with education, cultural beliefs and practices, behavioral sciences, agriculture, and socio-economic issues, nutrition had the additional potential that it would let me work in any corner of the world.

After receiving my credentials as a physician, I started working on the nutritional problems of a 'developed' country-Italy. I studied the effects of poor diet and lack of physical activity as risk factors for chronic degenerative diseases. To turn to the nutritional problems of developing countries, I needed specific qualifications. Luca encouraged me to write to twenty international universities offering Master's Degrees in nutrition, to determine which curriculum would best match my interests. The program offered by the London School of Hygiene and Tropical Medicine, with over one hundred years of experience in research and training in developing countries, including the medical, cultural, agricultural, and social aspects of nutrition, was my first choice.

Luca continued to follow my work in this new direction and with Alba, visited me and my wife, Kim, in various countries where I worked: in China, where I was responsible for an Italian cooperation program in 
1989, in Malaysia, where our son Manuele was born in 1992, and in the Philippines, where I worked for almost twenty years as the WHO Regional Adviser on Nutrition.

\section{Mathematics and Statistics}

Matteo: Luca was a good mathematician-mostly self-taught-because Italian schools offered few math courses at the time when he (and even I) grew up. He did his best to educate me in this field, which turned out to be essential for his most important contributions to the study of the evolution of the human species: the genetics of human populations and the evolution of culture. I have vivid childhood recollections of seeing him doing calculations elbow-to-elbow with Anthony Edwards, also a disciple of Sir Ronald Fisher, in our Milan apartment. Much later, at Stanford, as an adult, I was always impressed seeing him fill pages and pages of formulas, in collaboration with Marc Feldman.

Violetta: I was reasonably good in math, but I had a harder time understanding statistics despite Luca's many attempts to explain its basic principles to me. Still, I loved logic, so the transition to computer science came rather naturally, considering how the field exploded in Silicon Valley and elsewhere in the early 1980s. Retrospectively, I think that in my choice of studies I was also unconsciously moving away from pursuing a career that might put me in competition with Luca as a scholar.

Growing up and becoming a young professional at Stanford and its surroundings, having Luca's colleagues as well as mine nearby, it was impossible not to be confronted with the very highest levels of intelligence displayed by those I worked with and to escape comparison. This environment, and the debates on race and human intelligence that Luca had with William Shockley in the early 1970s, steered my interests towards intelligence, reasoning and learning, and how to support them with the computational tools of artificial intelligence. I devoted my Ph.D. studies to this topic, and I continue to address it in my current role as faculty member, teacher, researcher, and head of the faculty development center at my university.

Tommaso: Luca encouraged me to work in the first Italian outpatient university center for the treatment and prevention of diabetes, obesity, and dyslipidemia, in Parma, where I could combine clinical practice and research. He followed my research work from abroad and more closely during his periodic visits to Italy when he spent much time teaching me statistics and encouraging me to use a calculator to do statistical tests. This helped me to understand how to apply statistical tests throughout my working life.

Francesco: I always liked numbers, but my math training stopped at trigonometry, and I did not come across many numbers in philosophy 
or in film. Still, reading and writing on evolution with my father and studying journal articles, I came to realize the importance of mathematical models and statistical analysis in sorting out hidden patterns in a set of data. These indispensable scientific tools can extend our sight beyond the visible horizons, as in the amazing reconstruction of the history of living species made possible by DNA-based phylogenies. I tried to learn as much as I could by observing the world of numbers from the outside, knowing that to enter it I would have to wait for another lifetime.

I have many keen memories from the long periods I spent with my parents at Stanford, over almost twenty years (1991-2008). One of these concerns the meetings that Luca had after dinner with Marc Feldman. He lived right around the corner from us and would visit Luca one or two evenings every week. They sat for hours in the two armchairs in Luca's studio, discussing and devising plans. I did not take part in their conversations, but I admired the intensity and passion emanating from their meetings, as it does from their work. The impression I received will stay with me forever.

\section{Biocultural Evolution}

Francesco: In studying philosophy, I was interested in communication, and in what we can and cannot say with words. I soon discovered the boundless pleasure of studying history, as human deeds are surely the one thing we may understand with a fair amount of certainty since they were the work of humans like us. With father, we always spoke at length about people, places, and times in history. I would say it was our favorite subject of conversation, beyond the work we had in common.

Through my father's research, I became acquainted with the genetics of human populations. Retracing the steps of cultural change, I soon realized how Luca's approach afforded an unprecedented view of human evolution as it relates to our history. This approach is often termed multidisciplinary, but might better be called holistic, as it takes into consideration everything we can trace of our past, from genes to ideas, behaviors, and technologies. From this theory of cultural change, I discovered a comprehensive frame of reference to understand the processes that have brought humanity to where we stand today. It has been the hallmark of my inquiry ever since.

Violetta: Another precious legacy I received from Luca was love for the study of language, and a certain predisposition to learn new ones. My father, as an adult, knew three modern languages, in addition to his native Italian and to Latin and ancient Greek, which he had studied at school. He strongly believed that knowing foreign languages was important for professional development and made sure that his children would have an opportunity to acquire this skill. As we were 
growing up, all of us siblings studied French in the Italian public schools, where it was taught reasonably well, and had nannies and private lessons for English. Luca was the only one who learned German (he told us that to learn it without a teacher he had translated a whole science book). Then, as we all went our way as adults and settled down in different parts of the world, each of us developed those languages that were useful to our personal and professional life.

The study of language was most important for me, first because it accompanied my favorite hobby for many years-folk dancing-as well as my romantic relationships; then, because it became a useful skill to have at hand as my professional interests grew to encompass natural language processing by computer. Becoming familiar with different languages and scripts, though with widely varying levels of proficiency, has been an unending source of richness in my life, as has the curiosity to explore new fields of study that promised to enlarge the boundaries of my work. That is another legacy from Luca that I can only be very grateful for.

Francesco: From 2006 to 2016, Luca and I gave a course together every year, at the Faculty of Philosophy of San Raffaele University in Milan. I carried on the course myself in the last few years, when the teaching effort had become too great for my father. It was called Genetics and Anthropology, and beyond the pleasure of developing it together, it was a great way of introducing students of humanities to quantitative science and the global approach to the understanding of biological and cultural evolution. I often thought that it had to be the only course of its kind on the planet. For sure, it was the only science course taught by the Faculty of Philosophy!

Tommaso: If personal evolution has a part under this heading, I have to stress the importance our parents placed on keeping us kids strongly knit together and in stimulating us to explore the world and move about freely. In 1967, when I was 16, Luca and Alba decided it was time for us brothers to go to England to improve our English. Francesco was then 17 and got his driving license when in England, while Matteo, who was 20 , drove us all in his car, with camping tents, from Milan to London and Bournemouth. This journey consolidated our relation as brothers and our ability to get by on our own in new countries while testing our limited foreign language skills.

At the age of 17, I was allowed to travel independently, with friends by train and hitch-hiking. I thus got to know central and southern Italy better as far as Sicily and the Aeolian Islands. Between '68 and '69, Francesco hitch-hiked all across Europe, from Milan to Budapest to London, then from Los Angeles to Mexico City and back, and from San Francisco to New York. In the early 1970s, I traveled twice from Milan to Kathmandu by land, a three-month journey not possible today, but at the time a true pilgrimage to the East that many young people 
undertook; this ultimately proved important for my decision to work in developing countries. Our parents and Violetta moved to Stanford in September 1971, when Luca took up a full professorship at the Department of Genetics. From the early 1970s, Francesco and I found ourselves in the enviable situation of having an apartment in Milan with our wonderful paternal grandmother next door, to look after each other. As we were both in our early twenties, this was a great gift for us. We went to university and started work while living in the house where we had grown up, with family and friends in town, maintaining regular correspondence with our parents. At this time, most kids would flee from their parents' home; we had the good luck that our parents fled and left us the home.

\section{The Pioneer}

Francesco: In the twenty-plus years I spent working with my father, or in close contact with him, I learned a lot about his work and his progress as a researcher (it seems truer to him to speak like this rather than of his 'career in science'). Together we wrote his autobiography, Perché la scienza? - L'avventura di un ricercatore (Milano 2003; "Why science? - The adventure of a researcher"), which was later published in French but not in English.

Luca engaged in research in the early 1940s, while studying medicine at the University of Pavia, under the guidance of Adriano Buzzati-Traverso towards the end of the curriculum. By the early ' 50 s he had mastered both population genetics and statistics, extending his studies from mice, Drosophilae and plants into bacteria, working mainly with Fisher and then with Joshua Lederberg. In 1950, once he realized there was little chance for him to carry on research at Cambridge, as the University (which was at odds with Fisher) would not give him a stable position, he returned to Italy. He took back his former job as bacteriologist in a pharmaceutical company, and taught his subjects in university courses in Pavia and Parma. Meanwhile, the family kept growing.

Research in Italy was underdeveloped after the twenty years of an isolationist regime and the war, which had swept throughout the country. Also, the prevalence of the Catholic Church and its ideology had downplayed the importance of science for centuries. Luca realized, as he told me, that there was no way to compete with the research that was developing at a fast space in the U.S. and in England, especially after the discovery of the structure of DNA had begun to rewrite biology. So, he looked for a direction of research which no one else had approached, where one could start anew. Man had been his main interest since he had entered the Faculty of Medicine and he turned to consider whether it would be possible to reconstruct the biological as well as the cultural history of our species. This was considered unthinkable at the time, yet the tools were there: genetics, statistics, history, anthropology, 
archaeology. In the course of time, he would bring these disciplines together to cooperate.

Blood groups were among the few genetic markers then available. By collecting and analyzing blood samples from the inhabitants of 62 villages in the Parma Valley, and by checking it against the village genealogies of the past 400 years collected from parish books, he was able to provide the first experimental evidence of the importance of drift in human evolution. By the early ' 60 s, a sizeable mass of data on blood groups worldwide had become available, and it was possible to analyze them using the early computers and to form a first evolutionary tree of humankind (with Anthony Edwards, 1963).

The road had been set. The many expeditions Luca conducted among the Pygmies (as the many Aka, Baka and other tribes were collectively called at the time) from 1966 onwards were aimed at collecting blood from some of the most ancient peoples on Earth still living as hunter-gatherers, to compare the data with that of modern populations. At the same time, it provided the opportunity to gather a wealth of anthropometric, medical, and cultural information.

Luca's research developed steadily over the years. With Walter Bodmer, they laid the groundwork of a new discipline, publishing their fundamental text, The Genetics of Human Populations, in 1971. Moving from Pavia to Stanford in the early 1970s, Luca was able to pursue research in a top notch scientific environment with resources unavailable in Italy; at the same time, he managed to promote a vast interconnection between different universities and research centres. With Marcus Feldman, they established the mathematical basis for the study of cultural evolution (1981). He and Albert Ammerman traced the diffusion of farming and farmers in Europe (1984). The monumental analysis described in the History and Geography of Human Genes (1995) was produced through the collaboration of Luca with Alberto Piazza and Paolo Menozzi.

Luca worked in multiple directions, tackling a number of medical issues, alongside his main interests. With linguists, he studied the evolutionary rates of linguistic change. In the year 2000, with the help of his Stanford lab team, he produced the first male evolutionary tree, based on the non-recombining region of the $Y$ chromosome; they also established an evolutionary tree of mitochondrial DNA and showed a correlation between geographic and genetic distance on a worldwide scale. At the same time, Luca was directing the writing of a History of Italian Culture, a 12-volume encyclopedia detailing most facets of Italian cultural history, published in 2011.

Once it became possible to sequence DNA, the Human Genome Project got underway and Luca proposed a Human Genome Diversity Project (HGDP) to obtain a worldwide view of human genetic differences. This was opposed from the very start by a number of groups, purportedly 
siding with aboriginal populations. These obstructions and the novelty of the proposed inquiry, which raised a number of potential issues, made it impossible to collect samples from many groups. To overcome the objections, Luca and his colleagues worked at length to draft a strong ethical protocol, meant to prevent any commercial or scientific abuse. Still, political and practical constraints prevented the HGDP from gathering the desired data from many populations in different regions of the world, even when there were research groups ready to carry out the inquiry locally. Thanks to the efforts of a number of scientists, it was nonetheless possible to form a Human Genome Diversity Panel, based in Paris, with a collection of blood samples from over 1,000 individuals from 51 populations worldwide. This has permitted an array of further research studies over the past twenty years.

Luca's innovative approach brought him much recognition, but also criticism, which he would always answer promptly and competently. He was dismayed by all the misunderstandings and hindrances met by the Diversity Project (a German ecological group called it The Vampire Project), but most of all by the way it prevented the carrying out of research on many aboriginal groups already on the edge of extinction. A colleague of his once quoted a saying from the old Wild West: You can recognize a pioneer by the arrows in his back.

\section{The Celebrity}

Francesco: The number of prizes, honorary degrees, medals and other awards received by Luca during his lifetime was astounding, yet over the years I never heard him boast of any of his achievements or recognition he received. If the word unassuming has meaning, it surely can be applied to him. His accomplishments simply fueled his enthusiasm for continued research.

He was a researcher of international renown in his own several fields, but in Italy he was mainly known for having refuted racism, by showing that the concept of 'race' does not apply to humankind. In his last book (Razzismo e noismo, 2013, only in Italian) he showed that racism was but one of the many sides of 'we-ness', the universal attitude of considering our own group to be the center of the world. On the Italian media, he was actually held in great esteem because of the we-ness stance, as he was one of the few Italian scientists of worldwide impact; but I think that few in the general public understood what all his work had been about.

In 2011, an unprecedented exhibit called Homo sapiens opened in Rome, displaying what was known about the deep past of our species. It had largely been inspired by Luca's outlook, and it was extremely successful. In the following years, it moved to other Italian towns. Going with Luca to the opening of one such later venue, I remember how he was greeted by universal applause as he entered the crowded congress hall. He 
spoke briefly, then moved towards the exit, not meaning to stay through the whole ceremony. As he walked out of the hall, the applause resumed and did not stop until the two of us were out on the street. Going down the road, Luca asked me: "Why do they cheer me like that?" "That's because of the work you did", I answered. "Come on! You have shown unforeseen ways of looking into our past." "What I did was just the smallest bit of work", he replied, putting his forefinger very close to his thumb. "It's all yet to be done."

In retrospect, I see him like one of those great spirits who built the foundation of our rational (and skeptical) thinking a thousand years ago-people like Ibn Sina and Al-Biruni-or the better-known researchers who ignited the scientific revolution of recent centuries, who were interested in looking into everything around us and in questioning every assumption.

There is a statement by Luca that we put as a heading on the website we created for him: The most important teaching of science is to say: I do not know.

\section{One Scientist, Two Parents: Setting the Example}

Matteo: Finally, a few words about the example Luca set for his children. Even though this contribution is about Luca's scientific legacy, it would be unfair not to mention how important our mother was in what Luca gave us. It is often said that behind a great man there is always a great woman.

Both our parents enjoyed exploring the world. There is hardly a country they did not visit, and they passed on to us their passion for exploration in both the physical and the intellectual domains; but, most of the time they just worked very hard at what each was most interested in or felt obliged to pursue. Their enthusiasm, but also their sense of what had to be done, drove their lives. I see in my siblings, each in their own way, the influence of the remarkable couple my parents were.

Violetta: Our mother was known as Pupa to her family and Italian friends and as Alba to her friends in the US. She did not pursue a career in biology, though she was studying it before meeting Luca and obtained a university degree in that field. She preferred to play a more traditional role at Luca's side, providing the home environment that allowed him and his children to prosper and find their ways in the world.

I, in particular, owe a huge debt to her in endless ways. She shared with Luca a love of travel and beauty, and a boundless curiosity, to which she added a good dose of perfectionism-characteristics we all inherited to a greater or lesser degree. What great luck to have parents such as these!

Tommaso: Each of us children received strong ethical principles from our parents, and was encouraged to choose a career based on profound 
personal interests, to enable us to work with passion. Dedicating a lot of time and energy to your work can lead to frustration when you cannot achieve what you aim for. An important principle my father taught me was that, if you do your best to achieve your goal and do not succeed, your heart will always be at peace, knowing you did what you could.

Francesco: It is all too easy to see our parents as a spring that fed with many streams the lives of their children. Something Luca made very clear is that the one real contribution one can give to others is through their example. Even if it goes unnoticed, I would say, still your example is the one solid thing that may reach others. As we once wrote in a book, in adult life, especially at difficult times, it will be important to reach out with your memory to the examples given by people you esteem and love.

Tommaso: If our father was very present as a scientist throughout our life, and less present in other aspects of our personal growth, in the last years of his life we witnessed a wonderful transformation. As his memory gradually faded, he remained interested in learning and meeting new and old friends. Some special aspects of his character emerged, that were perhaps previously hidden by his prevailing rational attitude: a great sensitivity and attention to others, leading him to ensure that any visitor was at ease and provided with whatever he needed. He also possessed the greatest affection and caring for his wife, who had dedicated her life to raising their children and supporting his career.

It was wonderful to see these aspects of his character flourish in the last years of his life, perhaps reflecting the love he received from his mother, which he reciprocated throughout his life. He was a truly gentle man. Lastly, he had a wonderful sense of humor, showing the wisdom of one who has lived long, seen, and understood much.

Cite this article: Cavalli-Sforza M, Cavalli-Sforza F, Cavalli-Sforza LT, Cavalli-Sforza V. LUCA, as our father. Hum Popul Genet Genom. 2021;1(1):0002. https://doi.org/10.47248/hpgg2101010002 